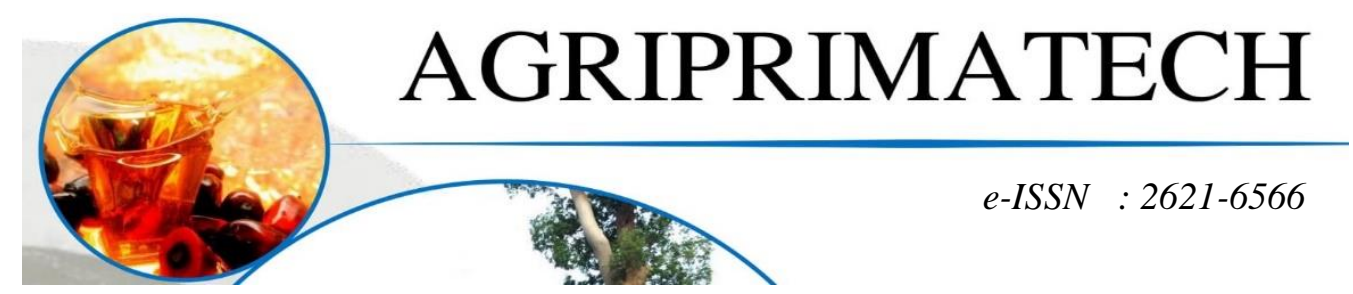

\title{
FAKTOR-FAKTOR YANG MEMPENGARUHI KEPUTUSAN PETANI DALAM MEMILIH BIBIT KELAPA SAWIT
}

\author{
LAURA JUITA PINEM ${ }^{1}$, MYRNA PRATIWI ${ }^{2}$ \\ 1,2 Fakultas Agro Teknologi, Universitas Prima Indonesia, Sumatera Utara \\ Email: laurajuitapinem@unprimdn.ac.id
}

\begin{abstract}
ABSTRAK
Penelitian ini bertujuan untuk mengidentifikasi karakteristik petani, menganalisis tahapan proses pengambilan keputusan pembelian petani dalam memilih bibit kelapa sawit, dan menganalisis faktor-faktor yang mempengaruhi proses pengambilan keputusan pembelian petani dalam memilih bibit kelapa sawit di Kabupaten Labuhan Batu Utara. Penelitian ini dianalisis dengan bantuan 100 responden. Metode yang digunakan dalam penelitian ini adalah analisis deskriptif dan analisis faktor. Hasil dari analisis faktor membentuk 3 faktor yang mempengaruhi, yaitu faktor Psycho personality, faktor Personal Marketing, faktor luas lahan
\end{abstract}

Kata Kunci : Keputusan, Petani, Bibit, Kelapa Sawit, Analisis

\section{PENDAHULUAN}

Selain pupuk, air, cahaya, dan iklim, salah satu faktor lain yang sangat penting diperhatikan oleh petani adalah bibit. Bibit yang bermutu rendah walaupun didukung oleh faktor-faktor produksi lainnya yang cukup maka hasilnya akan rendah karena mutu bibit mencakup mutu genetis, mutu fisiologis, dan mutu fisik. Mutu genetis menunjukkan identitas genetis dari tanaman induknya sedangkan mutu fisiologis merupakan kemampuan daya hidup (viabilitas) bibit yang mencakup daya kecambah dan kekuatan tumbuh bibit. Sedangkan mutu fisik menunjukkan penampilan bibit seperti ukuran homogen, bernas, bersih dari campuran, bebas hama dan penyakit, dan kemasan menarik.

Pembangunan pertanian tanpa
didukung oleh pembangunan
pembibitan dikhawatirkan akan
mengancam produktifitas tanaman
karena bibit diindikasi mempunyai
kontribusi yang sangat tinggi dalam
menentukan keberhasilan produksi dan
produktifitas tanaman. Semakin tinggi
mutu bibit yang digunakan maka
semakin besar produksi yang dihasilkan.
Salah satu bentuk pembangunan
pembibitan yang sedang digalakkan
adalah sertifikasi bibit kelapa sawit.
Sistem pengawasan mutu dan sertifikasi
bibit yang handal dapat melindungi
keaslian varietas dan kemurnian
genetik, baik yang diproduksi oleh
produsen maupun yang digunakan oleh
konsumen di lapangan agar sesuai
dengan standar mutu bibit yang berlaku.
Bibit yang bermutu tinggi diharapkan
menjadi salah satu jaminan untuk


meningkatkan produksi, produktivitas, dan mutu hasil pertanian yang berdaya saing, dan pada akhirnya bisa berdampak positif terhadap pendapatan dan kesejahteraan petani.

Salah satu kabupaten di Sumatera Utara yang menempatkan kelapa sawit sebagai salah satu komoditas unggulan daerahnya adalah Kabupaten Labuhan Batu Utara. Banyak petani rakyat yang menggantungkan kehidupan mereka pada komoditas kelapa sawit. Ada sekitar 15.960 petani yang berkecimpung pada sektor ini. Tetapi produktifitas dari kelapa sawit yang dikelola oleh petani belum maksimal, hal ini ditunjukkan melalui data dari Direktorat Jenderal Perkebunan bahwa pada tahun 2016, Kabupaten Labuhan Batu Utara mempunyai luas area kelapa sawit sebesar 68.178 hektar dengan produktifitas $3.058 \mathrm{~kg} / \mathrm{ha}$ sedangkan data dari lembaga yang sama menunjukkan bahwa di Sumatera Utara perkebunan yang dikelola oleh perkebunan swasta dan negeri bisa mencapai produktifitas $4.415 \mathrm{~kg} / \mathrm{ha}$. Salah satu alasan yang menjadi kemungkinan belum maksimalnya produktifitas kelapa sawit petani di Kabupaten Labuhan Batu Utara adalah karena penggunaan bibit palsu atau bibit yang tidak terjamin mutunya. Hal senada telah dianalisis Kariyasa (2015), dalam jurnalnya mengatakan bahwa petani yang menggunakan bibit bersertifikat mampu mengembalikan modal yang diinvestasikan lebih cepat jika dibandingkan dengan petani yang menggunakan bibit non sertifikat.

Banyaknya permintaan bibit menyebabkan tidak terpenuhinya permintaan bibit para petani kelapa sawit, hal ini merupakan salah satu peluang bagi produsen bibit tidak resmi (palsu). Penggunaan bibit palsu menimbulkan kerugian yang besar,karena produktifitas tanaman dari bibit palsu kurang dari setengah tanaman dari bibit unggul (litbang pertanian,2017). Beberapa produsen bibit kelapa sawit legal yang ada di Indonesia adalah, Pusat penelitian Kelapa Sawit (PPKS) Medan, PT. Socfin Indonesia, PT.PP London Sumatera,Tbk, PT Binasawit Makmur (PT Sampoerna Agro, Tbk), PT. Tunggal Yunus Estate (Asian Agri Group), PT. Dami Mas Sejahtera (Smart Group), PT. ASD-Bakrie Oil Palm Seed Indonesia (Dijetbun, 2016).

\section{METODE PENELITIAN}

Jumlah sampel yang digunakan dalam penelitian ini adalah 100 responden. Jumlah sampel ini didapat dengan merujuk kepada Rumus Slovin yang digunakan untuk menentukan ukuran minimal sampel yang dibutuhkan dari suatu populasi sehingga mendapatkan sampel yang mewakili populasi.

Dimana:

$$
\mathrm{n}=\frac{N}{1+\epsilon^{2} N}
$$

$\mathrm{n}=$ Besar sampel

$\mathrm{N}=$ Besar populasi

$\epsilon=$ Batas toleransi kesalahan (error tolerance) 10 persen

Teknik pengolahan dan analisis data yang digunakan adalah metode deskriptif kualitatif dan Analisis Faktor. Metode pengumpulan data yang dipakai pada penelitian ini adalah teknik angket (kuisioner). Kuisioner yang yang dipakai telah melalui proses validitas dan realibilitas terlebih dahulu sebelum digunakan sebagai instrumen penelitian. Kuisioner terbagi atas tiga bagian, bagian pertama merupakan karakteristik responden, bagian kedua merupakan pertanyaan-pertanyaan yang berkaitan dengan lima proses pengambilan keputusan konsumen, dan bagian terakhir berisikan pertanyaan yang faktor-faktor yang mempengaruhi perilaku konsumen. Data diolah dengan menggunakan Microsoft Excel 2007 dan SPSS VERSI 22.

Uji validitas merupakan alat ukur yang digunakan untuk menggambarkan tingkat kesahihan kuisioner. Validitas 
menunjukkan sejauh mana alat dapat mengukur apa yang ingin diukur (Umar, 2005). Uji validitas dapat diketahui dengan cara menghitung nilai korelasi $(r)$ antara data pada masing-masing pernyataan dengan skor tota. Rumus yang digunakan adalah rumus tekhnik korelasi Product Moment Pearson sebagai berikut :

$$
r=\frac{n\left(\sum X Y\right)-\sum X-\sum Y}{\sqrt{\left(n \sum X^{2}-\left(\sum X\right)^{2}\right)\left(n \sum Y^{2}-\left(\left(\sum Y\right)^{2}\right)\right.}}
$$

Keterangan :

$r=$ Koefisien validitas yang dicari

$\mathrm{n}=$ jumlah responden

$X=$ Skor masing-masing pertanyaan $X$

$Y=$ Skor masing-masing pertanyaan $Y$

Uji realibilitas merupakan uji yang digunakan untuk menunjukkan konsistensi suatu alat ukur dalam mengukur gejala yang sama (Umar, 2005). Uji realibilitas yang dipakai terhadap kuisioner yang dipakai pada penelitian ini menggunakan metode Cronbach's Alpha dengan rumus :

$$
r_{11}=\left(\frac{k}{k-1}\right)\left(1-\frac{\sum \sigma_{b}^{2}}{\sigma_{t}^{2}}\right)
$$

\section{Keterangan:}

$\mathrm{r}_{11} \quad=$ reliabilitas instrumen

$\mathrm{k} \quad=$ banyak butir pertanyaan

$\sum \sigma_{b}^{2}=$ jumlah ragam butir

$\sigma_{t}^{2} \quad=$ varians total

Rumus untuk mencari nilai ragam adalah:

$\sigma^{2}=\frac{\sum x^{2}-\left(\frac{\sum x^{2}}{n}\right)}{n}$

Keterangan:

$\sigma 2=$ ragam

$\mathrm{n}=$ jumlah sampel

$\mathrm{X}=$ nilai skor akhir

Analisis deskriptif bertujuan menyajikan data mentah yang didapat dalam penelitian menjadi lebih mudah untuk dipahami dengan membentuknya menjadi informasi yang ringkas. Sedangkan analisis faktor merupakan suatu teknik untuk menganalisis tentang saling ketergantungan dari beberapa variabel secara simultan dengan tujuan menyederhanakan bentuk hubungan beberapa variabel yang diteliti menjadi sejumlah faktor yang lebih sedikit dari variabel yang diteliti (Sulisyanto, 2005). Model analisis ini dikelompokkan menjadi 2, yaitu :

a. Analisis komponen utama (Principle Component Analysis), merupakan model dalam analisis faktor yang tujuannya untuk melakukan prediksi terhadap sejumlah faktor yang akan dihasilkan.

Model Principal Components Analysis :

$$
\begin{gathered}
F_{m}=I_{m} X_{1}+I_{m} X_{2}+\ldots I_{m p} X_{p} \\
\text { Syarat, } m \leq p
\end{gathered}
$$

Keterangan:

$\mathrm{F}=$ faktor principal component (unobservable)

$\mathrm{X}=$ variabel yang diteliti (observable)

I = bobot dari kombinasi linier (loading)

b. Analisis faktor umum (Common Factor Analysis), model dalam analisis faktor yang tujuannya untuk mengetahui struktur dari variabel yang diteliti (karakteristik dari variabel). analisis faktor digunakan untuk mengidentifikasi faktor-faktor yang mempengaruhi keputusan pembelian konsumen

\section{HASIL DAN PEMBAHASAN}

\section{Karakteristik Petani Kelapa Sawit}

Karakteristik petani kelapa sawit diperlukan dalam penelitian ini untuk mengetahui sejumlah ciri atau sifat yang dimiliki oleh petani kelapa sawit dalam mengambil keputusan pembelian bibit kelapa sawit serta faktor-faktor yang mempengaruhinya. Mengetahui karakterisktik dari petani merupakan salah satu informasi yang dibutuhkan 
produsen untuk menentukan segmentasi, target pasar dan positioning yang tepat (Kotler, 2016). Karakteristik responden yang digunakan dalam penelitian ini adalah usia, tingkat pendidikan, lama berusaha tani, luas lahan, status kepemilikan.

Petani kelapa sawit yang berada di Kabupaten Labuhan Batu Utara yang dianalisis didominasi oleh petani yang berada pada rentang usia 41-45 tahun. Menurut Bakir dan Maning (1984), umur produktif untuk bekerja di negara-negara maju pada umumnya adalah 15-55 tahun. Hal ini menunjukkan bahwa petani responden berada pada usia produktif sehingga petani pada usia ini masih memiliki keinginan untuk mengembangkan usahanya. Sedangkan tingkat pendidikan yang dienyam oleh petani yang dianalisis sekitar 54 persen menikmati pendidikan sampai level SMA. Tingkat pendidikan yang dimiliki petani mempunyai pengaruh terhadap pola pola pikir dan daya nalar seseorang, biasanya seseorang yang mengenyam pendidikan cukup lama akan lebih rasional dalam bertindak dan menjalankan usahanya (Afrizon, 2012).

Tabel 1. Karakterisktik Responden Petani

\begin{tabular}{clcc}
\hline No & \multicolumn{1}{c}{ Karakteristik } & Kategori & Persentase (Persen) \\
\hline 1 & Usia & $41-45$ & 52 \\
2 & Pendidikan & SMA & 54 \\
3 & Luas Lahan & $0-5 \mathrm{Ha}$ & 83 \\
4 & Lama Berusaha Tani & $11-15$ Tahun & 40 \\
5 & Status Kepemilikan & Milik Sendiri & 100 \\
\hline
\end{tabular}

Luas lahan merupakan salah satu faktor produksi penting dalam usahatani. Besar kecilnya lahan mempengaruhi besar kecilnya pendapatan yang diperoleh dari usahatani (Edwina, 2014). Data yang didapat dari petani yang dianalisis menunjukkan bahwa sebanyak 83 persen petani mempunyai lahan sekitar 2-5 Ha. Berdasarkan luas lahan yang dimiliki oleh petani, petani mempunyai peluang untuk dapat berusahatani kelapa sawit dengan lebih baik sehingga produksi yang dicapai tinggi.

Ditilik dari pengalaman dalam berusahatani, petani yang dianalisis sekitar 40 persen sudah melakukan usahatani kelapa sawit selama 11-15 tahun. Lamanya berusahatani

\section{Proses Pengambilan Keputusan}

Proses pengambilan keputusan yang dilakukan konsumen meliputi pengenalan kebutuhan, pencarian informasi, evaluasi alternatif, keputusan merupakan pengalaman bagi petani yang mencerminkan kegiatan dan ketrampilan dalam mengelola usahataninya. Pengalaman cukup yang dimiliki petani akan melatih kemampuan dan kematangan petani dalam mempertimbangkan setiap langkah keputusan yang berkaitan dengan usahatani kelapa sawit yang sedang dijalankan. Hal ini sesuai dengan penelitian yang dilakukan oleh Edwina,2014.

Pada karakteristik status kepemilikan lahan, semua petani yang dianalisis mempunyai lahan sendiri untuk ditanami bibit kelapa sawit. Karakteristik dari petani responden disajikan pada Tabel 1.

pembelian dan perilaku pasca pembelian (Kotler, 2016). Tahapan yang pertama sekali yang dilakukan dalam proses pengambilan keputusan adalah tahap pengenalan kebutuhan (Tabel 2). Pada tahap pengenalan kebutuhan, 
petani memutuskan untuk memakai bibit dengan berbagai motivasi diantaranya 54 persen memilih karena kualitas bibit bagus sementara 27 persen memilih bibit karena harga terjangkau. Selain motivasi pada tahap pengenalan kebutuhan juga dilihat manfaat yang diinginkan petani dari bibit yang mereka pilih. 79 persen petani memilih bibit yang mereka pakai untuk meningkatkan produksi tanaman kelapa sawit yang mereka budidayakan di lahan mereka.

Tabel 2. Tahap Pengenalan Kebutuhan Petani

\begin{tabular}{clcc}
\hline No & \multicolumn{1}{c}{ Uraian } & Jumlah Responden (Orang) & $\begin{array}{c}\text { Persentase } \\
\text { (persen) }\end{array}$ \\
\hline 1 & Motivasi menggunakan Bibit & & \\
& a. Harga terjangkau & 27 & 27 \\
& b. Mudah diperoleh & 19 & 19 \\
c. Kualitas bibit bagus & 54 & 54 \\
d. Memperoleh keuntungan & - & - \\
& e. Pemakaian turun-temurun & - & - \\
\hline
\end{tabular}

2. Manfaat yang dicari

a. Meningkatkan jumlah produksi

$79 \quad 79$

b. Menghemat biaya produksi

14

14

c. Meningkatkan kualitas produksi

7

7

d. Mengurangi terkena hama dan penyakit

Setelah petani terangsang oleh kebutuhan akan bibit selanjutnya petani akan terdorong untuk mencari informasi yang lebih banyak berkaitan dengan bibit. Perolehan informasi mengenai kelemahan dan keunggulan bibit yang akan dipakai akan berpengaruh pada keputusan petani dalam memilih bibit. Tahap ini dinamakan tahap pencarian informasi. Bibit yang dipilih oleh 74 persen petani dipilih berdasarkan informasi yang didapat dari petani lain/kelompok tani. 56 persen petani percaya dengan informasi yang didapat dari petani lain/kelompok tani karena mereka bisa melihat langsung keunggulan dari bibit yang dipakai.Tahap pencarian informasi dapat dilihat pada Tabel 3.

Tahap berikutnya setelah petani melakukan pencarian informasi adalah tahap evaluasi alternatif. Petani pada tahap evaluasi alternatif memilih kriteria-kriteria tertentu yang relevan dengan keinginan dan kebutuhan untuk membuat keputusan pembelian bibit dengan menggunakan berbagai pertimbangan yang relevan. Berdasarkan penelitian yang telah dilakukan informasi penting yang dibutuhkan petani pada saat memilih bibit adalah kualitas bibit yang akan digunakan sebanyak 48persen petani . Persentase terbesar dari bahan yang menjadi pertimbangan petani dalam menggunakan bibit bersertifikat maupun bibit nonsertifikat adalah mengikuti petani lain. Salah satu alasan petani dengan mudah mengikuti petani lain dalam memilih bibit yang mereka pakai dikarenakan petani lain yang memberikan pengaruh dianggap lebih mempunyai pengalaman. Data dari tahap evaluasi alternatif dapat dilihat pada Tabel 4.

Tabel 3. Sumber Informasi yang Mempengaruhi Keputusan Petani

\begin{tabular}{ccc}
\hline & Jumlah Responden & Persentase \\
Uraian & (Orang) & (persen) \\
\hline
\end{tabular}


Agriprimatech

Vol. 3 No. 2, April 2020

e-ISSN :2621-6566

\begin{tabular}{lcc}
\hline Sumber Informasi & & \\
a. Pengalaman diri sendiri & 11 & 11 \\
b. Toko pertanian/pedagang bibit & 33 & 33 \\
c. Petani/Kelompok tani & 56 & 56 \\
d. Keluarga & - & - \\
\hline
\end{tabular}

Tabel 4. Evaluasi Alternatif Petani

\begin{tabular}{clcc}
\hline No & \multicolumn{1}{c}{ Uraian } & Jumlah Responden (Orang) & $\begin{array}{c}\text { Persentase } \\
\text { (persen) }\end{array}$ \\
\hline 1 & Informasi Penting & 48 & 48 \\
& a. Kualitas & 13 & 13 \\
& b. Produktifitas & & - \\
& C. Ketahanan terhadap & - & 21 \\
& $\quad$ hama dan penyakit & 21 & 18 \\
\hline & d. Harga bibit & 18 & \\
& e.Ketersediaan bibit & & 26 \\
$2 . \quad$ Pertimbangan Memilih & & 57 \\
& a. Kebiasaan yang & 26 & 17 \\
\hline & telah dilakukan & 57 & \\
& b. Mengikuti petani lain & 17 &
\end{tabular}

Selanjutnya petani akan membangun niat untuk memilih dan memutuskan untuk membeli bibit yang akan dipilih untuk digunakan dalam usahataninya. Tahap ini dinamakan tahap keputusan pembelian. Data dari petani menunjukkan bahwa pada tahap ini petani lebih dominan merencanakan terlebih dahulu sebelum melakukan pembelian bibit. Sebanyak 87 persen petani dengan melakukan perencanaan terlebih dahulu sebelum melakukan pembelian bibit. Sedangkan yang paling berpengaruh dalam proses pembelian yang dilakukan oleh petani adalah diri sendiri dengan persentase masingmasing sebesar 72 persen. Dalam memilih sumber bibit yang dipakai 52 persen petani memilih untuk membeli bibit dari petani lain yang sudah berpengalaman sebelumnya. Jarak merupakan salah satu alasan dari petani untuk tidak membeli secara langsung atau tidak bibit yang akan digunakan. Sebanyak 33persen petani rela untuk menempuh jarak $>10 \mathrm{~km}$ untuk mendapatkan bibit. Tabel 5 meyajikan secara lengkap data dari tahap keputusan pembelian.

Tahap terakhir dari proses pengambilan keputusan adalah tahap perilaku pasca pembelian. Pada tahap ini, petani sudah membeli dan menggunakan bibit sehingga petani sudah mempunyai melihat dan menilai hasil dari usahataninya. 59persen petani merasa puas setelah menggunakan bibit tersebut sedangkan 37persen petani tidak puas terhadap hasil usahataninya. Petani merasatidak puas terhadap bibit yang dipakai petani dikarenakan oleh pertumbuhan yang tidak seragam pada saat ditanam dilahan sampai dengan tanaman yang tidak berbuah walaupun sudah ditanam di atas 5 tahun.

Tabel 5. Keputusan Pembelian Petani Bibit Bersertifikat dan Nonsertifikat

\begin{tabular}{|c|c|c|c|}
\hline No & Uraian & $\begin{array}{c}\text { Jumlah Responden } \\
\text { (Orang) }\end{array}$ & $\begin{array}{c}\text { Persentase } \\
\text { (persen) }\end{array}$ \\
\hline
\end{tabular}


1 Cara Pembelian Bibit
a. Terencana
87
87
b. Tidak Terencana
2
2
c. Tergantung situasi
11
11

2. Yang berpengaruh dalam proses pembelian
a. Diri Sendiri
72
72
b. Toko pertanian/pedagang bibit
c. Petani/kelompok tani
-
d. Keluarga
21
21
7
7

3 Sumber Bibit
a. Membuat sendiri
4
4
b. Membeli dari petani lain
52
52
c. Koperasi
13
13
d. Tengkulak bibit
31
31

4. Jarak Tempat Pembelian Bibit
a. $1-5 \mathrm{~km}$
42
42
b. $6-10 \mathrm{~km}$
25
25
c. $>10 \mathrm{~km}$
33
33

Tabel 6. Perilaku Pasca Pembelian Petani Bibit Bersertifikat dan Nonsertifikat

\begin{tabular}{|c|c|c|c|}
\hline No & Uraian & Jumlah Responden (Orang) & $\begin{array}{c}\text { Persentase } \\
\text { (persen) }\end{array}$ \\
\hline \multirow[t]{4}{*}{1} & Kepuasan membeli bibit & & \\
\hline & a. Puas & 59 & 59 \\
\hline & b. Biasa saja & 4 & 4 \\
\hline & c. Tidak puas & 37 & 37 \\
\hline \multirow[t]{3}{*}{2.} & Niat membeli kembali & & \\
\hline & a. $\mathrm{Ya}$ & 62 & 62 \\
\hline & b. Tidak & 38 & 38 \\
\hline \multirow[t]{3}{*}{3} & Jika Harga Bibit Naik & & \\
\hline & a. Tetap membeli bibit & 63 & 63 \\
\hline & b. Tidak membeli bibit & 37 & 37 \\
\hline \multirow[t]{3}{*}{4.} & Varietas bibit tidak tersedia & & \\
\hline & a. Mencari di tempat lain & 34 & 34 \\
\hline & b. Membeli varietas lain & 66 & 66 \\
\hline \multirow[t]{3}{*}{5.} & $\begin{array}{l}\text { Menyarankan orang lain untuk } \\
\text { membeli bibit }\end{array}$ & & \\
\hline & a. Ya & 59 & 59 \\
\hline & b. Tidak & 41 & 41 \\
\hline
\end{tabular}

Kepuasan yang dirasakan petani pada saat menilai hasil dari bibit berdampak pada niat petani untuk membeli kembali bibit yang sama.
Sebanyak 62 persen petani berniat untuk membeli kembali bibit yang pernah mereka pakai sementara sisanya tidak berminat membeli kembali bibit yang mereka pakai walaupun ada yang 
merasa puas dengan hasil bibit. Hal ini disebabkan oleh pengaruh petani lain yang mengganggap bahwa produktifitas akan lebih tinggi bila menggunakan bibit lain yang disarankan.

Harga merupakan salah satu faktor penentu keputusan petani dalam membeli bibit. Bila harga naik dari 100 persen responden yang dianalisis hanya 63 persen responden yang berniat untuk membeli kembali bibit yang sudah pernah digunakan sedangkan sisanya lebih memilih untuk tidak membeli bibit . Jika varietas bibit yang dipakai tidak tersedia sebanyak 66 persen petani akan memilih bibit dengan varietas lain.

Kepuasan petani melihat hasil dari bibit yang mereka pakai merupakan sarana promosi yang dapat diandalkan. Petani yang berpengalaman dalam memakai bibit akan menjadi pemberi saran bagi petani pemula. Sebanyak 59 persen petani menyarankan orang lain untuk membeli bibit yang dipakainya sementara petani lain lebih memilih untuk tidak menyarankan penggunaan bibit yang mereka pakai kepada petani lain dikarenakan petani tidak merasa puas dengan hasil yang didapat.

\section{Analisis Faktor}

Analisis faktor merupakan instrumen yang digunakan untuk mengetahui faktor-faktor apa saja yang paling berpengaruh terhadap keputusan tersebut. Analisis ini mereduksi sejumlah variabel menjadi lebih sedikit kemudian menamakannya sebagai faktor.Terdapat 3 faktor yang mempengaruhi petani dalam mengambil keputusan pembelian diantaranya faktor (1) Psycho personality menunjukkan bahwa pengalaman yang dimiliki oleh petani membawa pengaruh terhadap psikologis petani dalam memilih bibit, semakin lama pengalaman petani dalam berusahatani kelapa sawit maka semakin semakin sulit untuk dipengaruhi,(2) faktor Personal Marketing, pada faktor ini petani melihat bahwa harga yang sesuai dengan kualitas bibit serta ketersediaan bibit yang berkesinambungan merupakan pendorong petani untuk menggunakan bibit kelapa sawit,dan (3) faktor luas lahan, merupakan faktor terakhir yang menjadi pendorong petani dalam memakai bibit kelapa sawit, luas lahan yang memadai akan membuat petani lebih selektif dalam memilih bibit yang akan digunakan.

\section{KESIMPULAN}

Proses pengambilan keputusan pembelian petani terbagi atas 5 tahap, yaitu: (1) Tahap pengenalan kebutuhan, pada tahap ini 54 persen petani memutuskan untuk memakai bibit karena kualitas bibit bagus dan 79 persen petani memilih bibit yang mereka pakai untuk meningkatkan produksi tanaman kelapa sawit yang mereka budidayakan di lahan mereka.

(2) Tahap pencarian informasi, pada tahap ini 74 persen petani memilih bibit berdasarkan informasi yang didapat dari petani lain/kelompok tani.(3) Tahap evaluasi alternatif, pada tahap ini kualitas merupakan informasi penting yang dibutuhkan 48 persen petani pada saat memilih bibit. (4) Tahap keputusan pembelian, pada tahap ini 87 persen petani melakukan perencanaan terlebih dahulu sebelum melakukan pembelian bibit, yang paling berpengaruh dalam proses pembelian yang dilakukan oleh petani adalah diri sendiri dengan persentase masing-masing sebesar 72 persen serta sumber bibit yang dipakai 52 persen petani memilih untuk membeli bibit dari petani lain yang sudah berpengalaman sebelumnya.(5) Perilaku pasca pembelian, pada tahap ini sebanyak 59 persen petani menyarankan orang lain untuk membeli bibit yang dipakainya. Terdapat 3 faktor yang mempengaruhi petani dalam mengambil keputusan pembelian diantaranya faktor Psycho personality, faktor Personal Marketing, faktor luas lahan. 
Agriprimatech

Vol. 3 No. 2, April 2020
e-ISSN :2621-6566

Bina Rupa aksara.

Ginanjar, G., Andayani, S.A \& Dinar. 2017. Analisis Faktor-Faktor yang Mempengaruhi Pengambilan Keputusan Petani Melakukan Usahatani Jagung Hibrida (Zea mays L). Jurnal IImu pertanian dan Peternakan, 5(02): 130-136

Joni, M.M.A, M.F.R. Rubzen, and P.J.Batt. 2001. Factors

influencing a farmer's decision to purchase seed potatoes in East Java. Paper presented at the 45th Annual Conference of the Australian Agricultural and Resource Economics Society, Adelaide, South Australia.

Eliza., Sayamar. E \& Cory. S. 2011. Analisis Faktor-Faktor Yang Mempengaruhi Konsumen Dalam Pengambilan Keputusan Pembelian Buah Di Pasar Arengka ( Pasar Tradisional Dan Giant Hypermarket (Pasar Modren) Di Kecamatan Tampan Kota Pekanbaru. Indonesian Journal of Agricultural Economics (IJAE) 2 (1)

Emiria, F. dan H. Purwandari. 2014. Pengembangan pertanian organik di Kelompok Tani Madya, Desa Kebonagung, Kabupaten Bantul, Daerah Istimewa Yogyakarta. Jurnal Penyuluhan 10 (2).

Direktorat Jendral Perkebunan.2015. Statistik Perkebunan Indonesia. Jakarta. Kementerian Pertanian.

Engel, James F, R.D Blackweel, P.J. Winiard. $1995 . \quad$ Perilaku Konsumen, Jilid 1. Jakarta:
Kotler, P. dan Kevin Lane Keller. 2007. Manajemen Pemasaran Edisi 12. Jakarta: Indeks.

Kotler, P. dan Garry Amstrong. 2016. Principles of Marketing. Pearson Education. England.

Schiffman, and Kanuk. 2008. Perilaku KonsumenEd 7. Jakarta: PT. Indeks.

Sumarwan, U. 2010. Perilaku Konsumen. PT Ghalia Indonesia, Anggota IKAPI,Bogor.

Suryani, T. 2008. Perilaku Konsumen: Implikasi Pada Strategi Pemasaran. Graga Ilmu. Yogyakarta.

Umar, H. 2005. Riset Pemasaran dan Perilaku Konsumen. PT Gramedia Pustaka Umum. Anggota IKAPI. Jakarta 